\title{
Research on Mechanical and Electrical Properties of Carbon Nanotubes Reinforced Cement- based Materials
}

Tian Xiushu, Wu Dongdong, Liu Qiongyao, Konglijuan

Faculty of Material Science and Engineering, Shijiazhuang Tiedao University. Hebei, 050043, China. E-mail: tianxiushu@163.com,846007137@qq.com,1101926186@qq.com,konglijuan_888@163.com

In this paper, the effects of carbon nanotubes on the mechanical and electrical properties of cement-based composites at different ages have been studied. The structures were characterized by SEM. The experimental results show that the higher content of carbon nanotubes may enhance the strength, when the content of carbon nanotubes is $0.1 \%$, the 3d flexural strength increases about $60.6 \%$, 28d strength increases about $57.4 \%$, the $3 \mathrm{~d}$ compressive strength increases about 33\%, 28d strength increases about $11.6 \%$. Highly dispersed carbon nanotubes can form uniform network structure in cement paste, so the mechanical properties of composites can be greatly improved. The conductivity of specimen increase with the content of carbon nanotube increasing, but decline as the content is more than $0.1 \%$, the rate of decline is slow. Carbon nanotube is conductive, they superpose each other and form the conductive network, which can make the cement based material capable of conducting. SEM pictures show that dispersion of the carbon nanotubes in the cement matrix is difficult when the content is more than $0.2 \%$.

Keywords: Mechanical properties, Electrical properties, Carbon nanotube

\section{Acknowledgements}

The writers are grateful for support provided through the Natural Science Foundation of Hebei Province of China (E2015210083).

\section{References}

[1] KANG, I., YUN, Y. H., KIM, J. H., et al. (2006).Introduction to carbon nanotube and nanofiber smart materials. Composites Part B: Engineering, Vol. 37, No. 6, pp. 382-394.

[2] MUSSO S., TULLIANI J.M., FERRO G., TAGLIAFERRO A. (2009). Influence of carbon nanotubes structure on the mechanical behavior of cement composites. Composites Science and Technology, Vol. 69, pp. 1985-1990.

[3] BELYTSCHKO, T., XIAO, S.P., SCHATZ G.C., RUOFF R.S. (2002). Atomistic simulations of nanotube fracture, Physical Review B: Condensed Matter and Materials Physics, Vol. 65, No. 23, pp. 235430-235437.

[4] GENG B.Y., NI W., WU H., CUI X. (2016). On high-strength low-shrinkage ITOs-based concrete, International Journal of Heat and Technology, Vol. 34, No. 4, pp. 677-686.

[5] MARÍA D.C.C., OSCAR G., FRANCISCO J.B., EMILIO Z., PEDRO G. (2014). Mechanical Properties and Durability of CNT Cement Composites. Materials, Vol. 7, No. 3, pp. 1640-1651.

[6] JAN Z., MIROSLAV M. (2016). Research on Mechanical Properties of Adhesive Bonds Reinforced with Fabric with Glass Fibres. Manufacturing Technology, Vol. 16, No. 1, pp. 299-304.

[7] WEN M., LUO J.X. (2015).Study on Mechanical Properties of the Composite Resin Matrix Fiber Reinforced. Manufacturing Technology, Vol. 15, No. 2, pp. 243-249.

[8] FAN J., XIONG G.J., Li G.Y. (2014). Progress in research and development of carbon nanotubes-reinforced cement-based composite materials. Materials Review, Vol. 11, pp. 142-148.

[9] WANG B.M., SONG K. (2011). Research progress in carbon nanotubes-reinforced cement-based composite materials, Low Temperature Architecture Technology, Vol. 5, pp. 1-4.

[10] MA Y., WANG D., WANG Q. (2014). Preparat ion of multi-wall carbon nanotubes renforced cement composites and study of its mechanical properties. Concrete, Vol. 6, pp. 72-74+77.

[11] ZHAO J.J., REN S.X., DU Y.L., ZHU W.H., WANG W.N. (2013). Study on the influence of carbon nanotubes on the mechanical properties of portland cement. Bulletin of The Chinese Ceramic Society, Vol. 32, No. 7, pp. 1361-1366+1370.

[12] WANG B.M., LIU S. (2013). Exploration into micromechanism of carbon nanotubes improved cement-based materials. Low Temperature Architecture Technology, Vol. 12, pages 1-3.

[13] ZHANG J.L., ZHU H.B., LIU X., YUAN Y. (2012). Research on dispersion of carbon nano tubes in cement based composite. Journal of Wuhan University of Technology, Vol. 34, No. 5, pp. 6-9. 
[14] HU S.G. (2009). Advanced cement-based composites, pp. 64-66.

[15] WANG B.M., HAN Y., LIU S. (2003). Effect of highly dispersed carbon nanotubes on the flexural toughness of cement-based composites. Construction and Building Materials, Vol. 46, pp. 8 -12.

[16] CUI X.W., WEN N.W., REN C. (2016). Early hydration kinetics of cementitious materials containing different steel slag powder contents, International Journal of Heat and Technology, Vol. 34, No. 4, pp. 590-596.

[17] LI G.Y., WANG P.M. (2005). Micro-structure and mechanical properties of carbon nanotubes-cement matrix composites. Journal of The Chinese Ceramic Society, Vol. 33, No. 1, pp. 105-108.

[18] OSCAR M., GERMÁN S., JORGE I.T. (2013). Influence of super plasticizer and Ca (OH) $)_{2}$ on the stability of functionalized multi-walled carbon nanotubes disp ersions for cement composites applications. Construction and Building Materials, Vol. 47, pp. 771-778.

\section{Paper number: M201774}

Copyright (C) 2017. Published by Manufacturing Technology. All rights reserved. 